\title{
Pure Gold-Green Sweat Bee Augochlora pura (Say 1837) (Insecta: Hymenoptera: Halictidae: Halictinae) ${ }^{1}$
}

\author{
Clancy A. Short and Andrea Lucky²
}

\section{Introduction}

Augochlora pura (Say), known as the pure gold-green sweat bee, is a solitary sweat bee native to the eastern United States with striking green iridescence (Figure 1). This species is an important native pollinator in eastern deciduous forests and other habitats. It emerges in spring and remains active throughout the summer and early fall. As the common name of this group suggests, these sweat bees are attracted to human sweat, which they lick to consume salts (Barrows 1974).

\section{Synonymy}

Synonyms of Augochlora pura Say (1837) are:

Halictus purus Say (1837) (original description)

Junior synonyms:

Oxystoglossa pura Say (1837)

Augochlora festiva Smith (1853)

Augochlora robertsoni Cockerell (1897)

Augochlora banksiella Cockerell (1907)

Halictus astios Vachal (1911)

Halictus asaphes Vachal (1911)

Augochlora palmarum Cockerell (1922)

Augochlora mosieri Cockerell (1922)

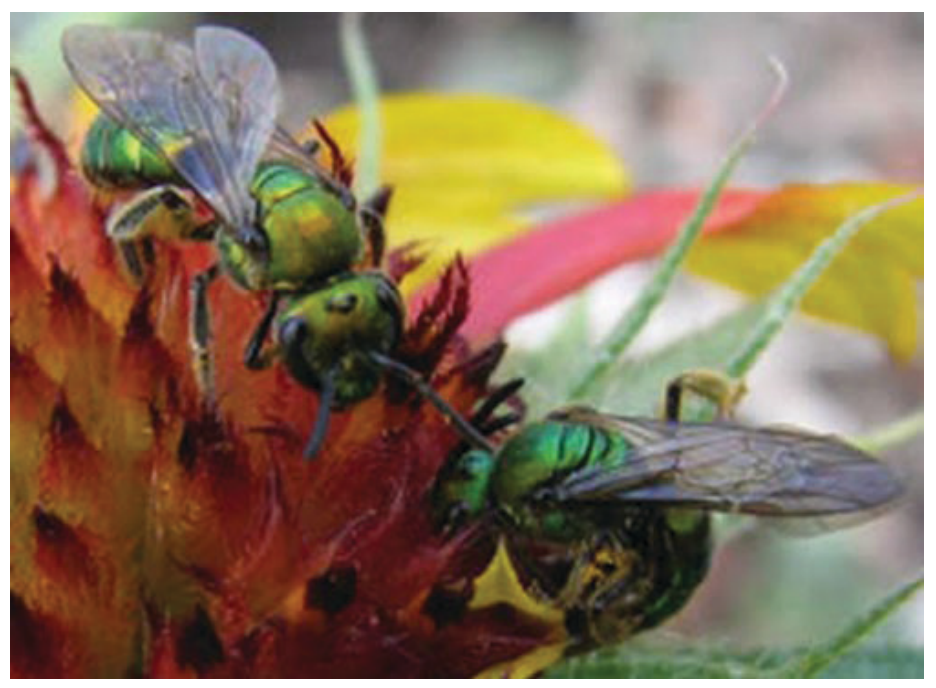

Figure 1. Two adult Augochlora pura (Say) collecting pollen and nectar from a flower.

Credits: Beatriz Moisset, pollinators.blogspot.com

\section{Distribution}

Augochlora pura can be found as far north as Quebec and as far south as Florida in the eastern United States. The western edge of its range stretches from Minnesota to Texas (Mitchell 1960). It is active from February to November in the southern portion of its range, but only from April to September in the northern part (Mitchell 1960). Augochlora pura is most commonly found in and adjacent to wooded areas (Stockhammer 1966).

1. This document is EENY-715, one of a series of the Department of Entomology and Nematology, UF/IFAS Extension. Original publication date September 2018. Visit the EDIS website at https://edis.ifas.ufl.edu for the currently supported version of this publication. This document is also available on the Featured Creatures website at http://entomology.ifas.ufl.edu/creatures.

2. Clancy A. Short; and Andrea Lucky, Department of Entomology and Nematology; UF/IFAS Extension, Gainesville, FL 32611.

The Institute of Food and Agricultural Sciences (IFAS) is an Equal Opportunity Institution authorized to provide research, educational information and other services only to individuals and institutions that function with non-discrimination with respect to race, creed, color, religion, age, disability, sex, sexual orientation, marital status, national origin, political opinions or affiliations. For more information on obtaining other UF/IFAS Extension publications, contact your county's UF/IFAS Extension office. 


\section{Description}

\section{Nests}

Augochlora pura adult females build nests in moist rotting wood, often in abandoned insect burrows, where they construct galleries of multiple cells, each cell receiving one egg (Figure 2). Each cell is provisioned with a ball of pollen and nectar and lined with a wax-like substance secreted by female wax glands (May 1974). These nests may be built of three-dimensional clusters of cells, two-dimensional clusters of cells, or a one-dimensional row of cells, making Augochlora pura nests more architecturally variable than most other sweat bees (Stockhammer 1966). This variation may be due to the inconsistent material characteristics of rotting wood. Although adults of Augochlora pura are solitary, at high densities neighboring nests may be separated by only a thin wall of hardened wood pulp (Stockhammer 1966).

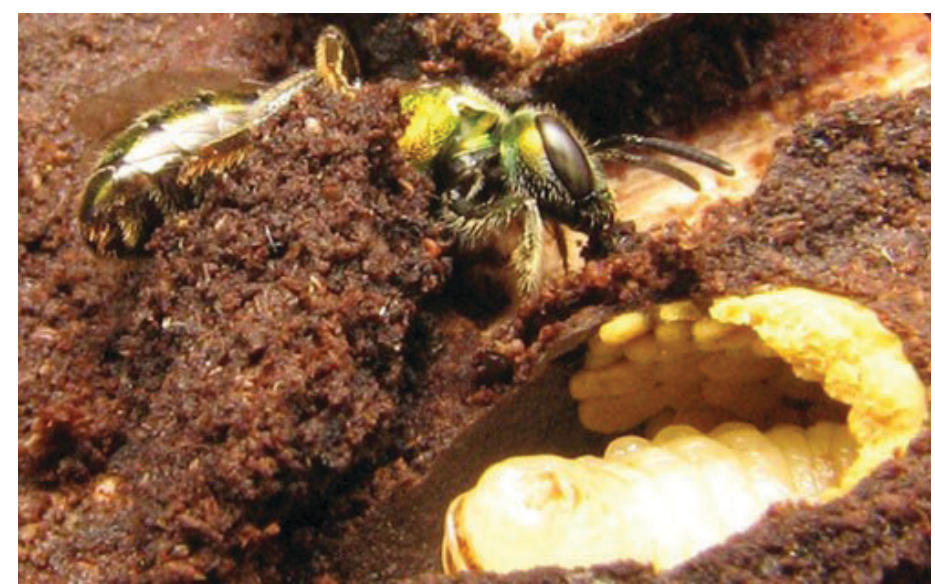

Figure 2. A partially excavated nest of Augochlora pura (Say) showing an adult (top left) and a larva within a wax coated cell (bottom right). Credits: Beatriz Moisset, pollinators.blogspot.com

\section{Eggs}

Pure gold-green sweat bee eggs are white and oblong, weighing approximately 2 to 3 milligrams and are laid on the surface of a pollen and nectar ball located inside the nest cell (May 1972).

\section{Larvae}

Larvae of the pure gold-green sweat bee grow from the size of the egg to up to $50 \mathrm{mg}$ (May 1972). They are soft bodied and white, without a noticeable head and with visible annulation of the body (i.e., body segments are visible). This appearance is typical of bee larvae.

\section{Pupae}

The female pupae weigh approximately $35 \mathrm{mg}$, and the male pupae weigh $20 \mathrm{mg}$ (May 1972). Like most bees, the pupae are difficult to identify out of context, but are always located within the nest cells created by the Augochlora pura adults. The pupae look like a pale white version of the adult, with the legs crossed over the ventral (underside) side of the body.

\section{Adult}

The adults of Augochlora are striking bees, with a heavily sculptured carapace (outer surface or exoskeleton). Numerous punctures cover the iridescent head, thorax, and abdomen. The striking colors of the adult carapace range from green to blue to gold. Though superficially similar to cuckoo wasps (Family Chrysididae), they can be distinguished by the presence of a curved basal vein in the forewing (Figure 3A), a typical venation pattern in all sweat bees (Halictidae).
A

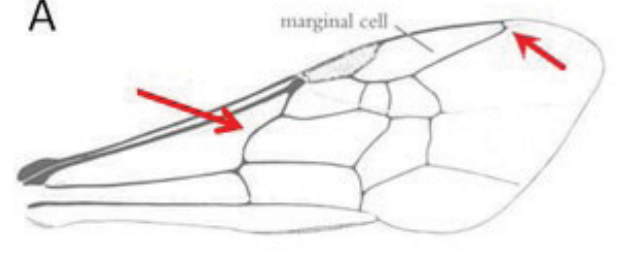

B

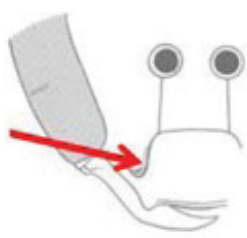

Figure 3. (A) The leftmost red arrow indicates the sharply curved basal vein characteristic of halictid bees and the rightmost red arrow indicates the truncated marginal cell characteristic of Augochlora. (B) The red arrows point to the genal lobes projecting over the clypeus, also characteristic of Augochlora.

Credits: Diagrams modified from Michener et al. (1994)

Females (Figure 4A) can be distinguished from males (Figure 4B) by the presence of pollen collecting hairs (scopa) on their hind legs, that are absent on the males. Males also have one additional antennal segment (females have 12 segments, while males have 13) and are usually smaller than females. Within the halictid bees, the genus Augochlora is distinguished from other genera by the squared-off marginal cell of the wing (Figure 3A), and the acute angle formed by the genal lobes (lateral projections) over the clypeus (front of face) (Figure 3B).

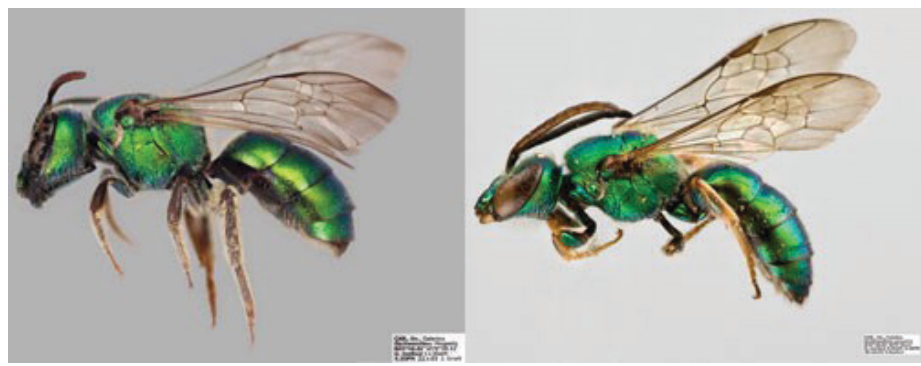

Figure 4. (A) Female and (B) male Augochlora pura (Say). The female has pollen collecting hairs on the hind leg and the male has an additional antennal segment. The female's stinger can be seen extending from the abdomen of live females.

Credits: Laurence Packer, York University 
Augochlora pura can be distinguished from other

Augochlora species based on its green coloration and the striations completely traversing its propodeal triangle (a distinctive plate immediately above the rear face of the thorax). However, no clear morphological traits distinguish Augochlora pura from the rare species, Augochlora azteca (Mitchell 1960), which is geographically restricted to Puerto Rico.

\section{Life Cycle}

Like other holometabolous insects (insects undergoing complete metamorphosis), Augochlora pura has four developmental stages: egg, larvae, pupae, and adult. Though the precise durations of the larval and pupal stages are unstudied, the time from egg to adult emergence ranges from 17 to 40 days depending on ambient temperature (Stockhammer 1966).

\section{Eggs}

The Augochlora pura eggs are sealed within the nest cell to prevent them from drying out and to protect the developing young. The waxy lining of the cells helps to maintain high humidity within the cell (May 1974). Male eggs are provided with a smaller pollen ball than female eggs, reflecting their smaller eventual adult size (May 1972). The duration of the egg stage is slightly over 24 hours in the warm conditions of summer (Stockhammer 1966).

\section{Larvae}

Augochlora pura larvae (Figure 2) consume the pollen and nectar ball while hidden away in sealed cells within the nest. The young larvae are still at high risk of drying out if the cell is damaged, but older larvae are less sensitive to desiccation (May 1972). Larvae form pre-pupae (an immobile stage immediately before pupation) once they have consumed the entire pollen ball and then form true pupae after they defecate (May 1972). Like many other hymenopteran larvae, the larvae of Augochlora pura do not defecate until the end of the prepupal stage. Larvae experiencing the higher ambient temperature typical of mid-summer $\left(\sim 30^{\circ} \mathrm{C}\right)$ develop faster than larvae reared at the lower temperatures of spring and early fall $\left(\sim 25^{\circ} \mathrm{C}\right)$ (Stockhammer 1966).

\section{Pupae}

The pupae are immobile, but during this stage the bees radically restructure their internal and external anatomy to assume the adult form. Internal folds of tissue are everted and stretched to form the wings, legs, and antennae, while the reproductive system develops internally. The pupae are more resistant to desiccation than the younger life stages (May 1972). The pupae molt into adults inside the cell and the adults remain inside the cell until their exoskeletons have hardened and they can chew their way out of the cell.

\section{Adults}

The adult bees consume a small portion of the nectar and pollen they collect for their offspring while visiting flowers. This species is not social, meaning that there is no division of reproduction or labor (i.e., each female builds her own nest and has her own offspring). Therefore, if a female returns to her nest and finds it occupied by another bee, she will use her powerful jaws to remove it, even if it is her own newly emerged offspring. Both male and female adults are present throughout the season, but males are more commonly laid in a nest's initial cells and are more abundant early in the season. Subsequently constructed cells are usually occupied by females, and adult females outnumber males later in the season (Stockhammer 1966).

The precise lifespan of the adults is not known, but females likely die after completing nine to 12 nests (Stockhammer 1966). There are typically two to three generations per year, and females of the latest generation overwintering after mating, either alone or huddled with other females, usually hidden away in insect burrows or old nests. In contrast, males die by the end of the fall and do not overwinter. In the northern section of its range, Augochlora pura probably has fewer generations per year because the growing season for flowering plants is shorter.

\section{Biology}

The biology of Augochlora pura has been well studied in the context of circadian (daily) rhythms. Adult females usually forage from morning to early afternoon, starting with nectar collecting trips followed by multiple pollen collecting trips (Stockhammer 1966). Females may make up to 10 pollen collecting trips to provision a single cell (Stockhammer 1966). In the early to mid-afternoon, the females guard their nests or condense pollen that they have collected into a pollen ball (Stockhammer 1966).

Females fight to defend their nest from conspecific (members of the same species) females and parasitoids, and usually avoid the nests of other females. Females construct new cells in the late afternoon and overnight. Females may also choose to re-use cells already constructed and vacated (Stockhammer 1966). At night females may shelter in their constructed nests or in logs if they are searching for a new nesting site (Stockhammer 1966). Though solitary, Augochlora pura females occasionally form aggregations 
in response to their own pheromones or the presence of salt (Barrows 1974). These female bees will lick sweat off humans and may sting if startled or threatened while consuming sweat.

Males do not participate in nest construction or provisioning. Males swarm in front of flowers and attempt to catch a female passing by and copulate with her (Stockhammer 1966). In the late afternoon, males return to logs or burrows, sometimes sharing these spaces with other conspecific males (Stockhammer 1966). Males occupy these burrows overnight and if the burrow is shared, all males face the same direction (Stockhammer 1966). The males of Augochlora pura have a weaker attraction to sweat than the females (Barrows 1974), and like all male wasps, cannot sting.

\section{Pollination}

Augochlora pura is a generalist pollinator and is known to collect pollen from more than 20 families of flowering plants. Augochlora pura adults forage primarily in forests and adjacent fields or prairies. Though Augochlora pura adults are generalist pollinators in terms of diet, females' nesting behavior is specialized, as they only nest in rotting wood. Augochlora pura adults can account for up to $90 \%$ of bees in the canopy of eastern woods in the United States (Ulyshen et al. 2010), and have been proposed to be one of the few animal pollinators of walnut (Stockhammer 1966). Augochlora pura adults are less likely to forage in the understory, but may still visit flowers there (Ulyshen et al. 2010).

\section{Management}

Augochlora pura females require decaying wood for nest construction, so cannot be managed using the nesting boxes, clusters of hollow twigs, or bee blocks (wooden burrows) commercially available for use by other solitary bee species. Augochlora pura is not commercially available for purchase. Given its nesting habitat, this species is likely to be more important in woodland ecosystems than in agroecosystems, though it may be an important crop pollinator in fields adjacent to woodland or in orchards.

\section{Natural Enemies}

Augochlora pura adults can fall prey to many predators specializing on flying insects, including spiders, birds, and other insects. It is possible females gain some protection because of their ability to sting. Their nests can be colonized by nematodes. The nematode Aduncospiculum halicti Giblin and Kaya, 1984 can be found living in more than half of
Augochlora pura nests. These nematodes do not seem to consume enough pollen to starve the larvae and do not feed on the larvae themselves (Giblin-Davis et al. 1990; McFrederick et al. 2013). Augochlora pura nests are likely subject to the kleptoparasitic bees and parasitoids that attack other bee nests, but no studies have confirmed the presence of these natural enemies.

\section{Selected References}

Barrows, E. M. 1974. "Aggregation behavior and response to sodium chloride in females of a solitary bee, Augochlora pura (Hymenoptera: Halictidae)." Florida Entomologist 57: 189-193.

Giblin-Davis, R. M., B. B. Norden, S. W. Batra, and C. Eickwort. 1990. "Commensal nematodes in the glands, genitalia, and brood cells of bees (Apoidea)." Journal of Nematology 22: 150-161.

May, D. G. 1972. "Water uptake during larval development of a sweat bee, Augochlora pura (Hymenoptera: Apoidea)." Journal of the Kansas Entomological Society 45: 439-449.

May, D. G. 1974. "An investigation of the chemical nature and origin of the waxy lining of the brood cells of a sweat bee, Augochlora pura (Hymenoptera, Halictidae)." Journal of the Kansas Entomological Society 47: 504-516.

McFrederick, Q. S., T. H. Roulston, and D. R. Taylor. 2013. "Evolution of conflict and cooperation of nematodes associated with solitary and social sweat bees." Insectes Sociaux 60: 309-317.

Michener, C. D., R. J. McGinley, and B. N. Danforth. 1994. The bee genera of North and Central America (Hymenoptera: Apoidea). 46, 59. Smithsonian Institution Press.

Mitchell, T. B. 1960. Bees of the eastern United States. I. Technical bulletin (North Carolina Agricultural Experiment Station) 456-458.

Stockhammer, K. A. 1966. "Nesting habits and life cycle of a sweat bee, Augochlora pura (Hymenoptera: Halictidae)." Journal of the Kansas Entomological Society 39: 157-192.

Ulyshen, M. D., V. Soon, and J. L. Hanula. 2010. "On the vertical distribution of bees in a temperate deciduous forest." Insect Conservation and Diversity 3: 222-228. 